\title{
Moringa Oleifera: an alternative ingredient to improve the egg quality of Japanese quail
}

[Moringa oleifera: um ingrediente alternativo na melhora da qualidade de ovos de codornas japonesas]

\author{
R.G. Garcia ${ }^{1}$, E.R.S. Gandra ${ }^{3}$, M.F.C. Burbarelli ${ }^{*}$, J.K. Valentim ${ }^{1}$, G.A. Felix ${ }^{2}$, \\ B.A. Lopes $^{2}$, F.B. Bacha', C.M.F. Melo ${ }^{4}$, J.P. Silva ${ }^{2}$, \\ C.M. Komiyama ${ }^{1}$, F.R. Caldara ${ }^{1}$
${ }^{1}$ Aluno de pós-graduação - Universidade Federal de Grande Dourados - Dourados, MS
${ }^{2}$ Centro Universitário da Grande Dourados - Dourados, MS
${ }^{3}$ Universidade Federal do Sul e Sudeste do Pará - Xinguara, PA \\ ${ }^{4}$ Universidade Estadual Paulista - Jaboticabal, SP
}

R.G. Garcia

https://orcid.org/0000-0002-4978-938 E.R.S. Gandra

https://orcid.org/0000-0002-4565-2817 M.F.C. Burbarell https://orcid.org/0000-0002-8079-2890 .K. Valentim https://orcid.org/0000-0001-8547-4149 G.A. Felix https://orcid.org/0000-0002-7739-586x B.A. Lopes https://orcid.org/0000-0003-1560-7676 F.B. Bacha https://orcid.org/0000-0002-1476-892 C.M.F. Melo https://orcid.org/0000-0001-6347-6012 J.P. Silva

https://orcid.org/0000-0001-7715-6255 C.M. Komiyama https://orcidorg/0000-0001-8732-5745 https://orcid.org/0000-0002-7564-6127

\begin{abstract}
This study aims to evaluate effects of inclusion of moringa in Japanese quail diets on laying performance, egg quality, blood parameters, serum biochemical profile, and behavior. One hundred and forty-four Japanese quails, approximately 35-d-old, were distributed in a completely randomized design with four treatments and six replications. Treatments were diet inclusion of $0,2,4$ and $6 \%$ of dried and ground moringa leaves. The inclusion of moringa in diets reduces the quadratic feed intake up to the level of $1.20 \%$, increases weight of eggs with a quadratic behavior up to $3.80 \%$, and linearly increases yolk weight. Yolk color changes with higher levels of inclusion of moringa and resulted in more intense colors. The biochemical profile of quails changed slightly but remains within the normal range. The inclusion of $4 \%$ of moringa in diets increases alkaline phosphatase. Regarding cholesterol and triglycerides, diet with $6 \%$ moringa inclusion was lower when compared to the others. The behavior of laying quails does not change due to inclusion of moringa in diets. Up to $3.83 \%$ of Moringa oleifera can be included in Japanese quail diet to improve egg quality without compromising performance, biochemical profile, blood parameters and behavior.
\end{abstract}

Keywords: antioxidants, egg quality, laying quails, medicinal plants, phytogenic additives

\section{RESUMO}

O objetivo deste estudo foi avaliar a inclusão de Moringa oleifera na dieta de codornas japonesas sobre o desempenho, a qualidade de ovos, os parâmetros sanguíneos, o perfil bioquímico e o comportamento. Foram utilizadas 144 codornas japonesas, com aproximadamente 35 dias de idade, as quais foram distribuídas em delineamento inteiramente ao acaso, com quatro tratamentos e seis repetições cada. Foram fornecidas dietas com 0, 2, 4 e 6\% de folhas desidratadas e moídas de moringa. A inclusão de moringa nas dietas reduziu quadraticamente o consumo até o nível de 1,2\%, aumentou o peso dos ovos com comportamento quadrático até o nível de 3,8\% e aumentou linearmente o peso da gema. A coloração da gema se intensificou com maiores inclusões de moringa. O perfil bioquímico sofreu alterações leves, mas não saiu dos padrões normais para codornas. A inclusão de 4\% de moringa nas dietas aumentou os níveis de fosfatase alcalina. Já a inclusão de $6 \%$ reduziu níveis de colesterol e triglicérides. O comportamento das codornas não se alterou com a inclusão de moringa nas dietas. A inclusão de até 3,83\% de Moringa oleifera na dieta de codornas japonesas aumenta a qualidade de ovos sem comprometer o desempenho, o perfil bioquímico, os parâmetros sanguíneos e o comportamento delas.

Palavras-chave: aditivos fitogênicos, antioxidantes, codornas de postura, plantas medicinais, qualidade de ovos

Recebido em 29 de setembro de 2020

Aceito em 19 de fevereiro de 2021

*Autor para correspondência (corresponding author)

E-mail: fariakita@gmail.com 


\section{INTRODUCTION}

Compounds extracted from medicinal or herbal plants have beneficial effects due to their antioxidant action and improving nutrient digestibility. They stimulate enzyme secretion and benefit intestinal microflora, and consequently provides better performance, greater feed conversion and, higher egg production in laying birds, in addition to an increased internal egg quality (Boka et al., 2014). We highlight the use of moringa (Moringa oleifera), which has several functions and applications in agriculture, medicine, and animal and human nutrition (Ndubuaku et al., 2015). The fresh leaves have excellent nutritional qualities, as a good protein source, containing about $33.8 \%$ protein (Gallão et al., 2006). It also contains vitamin A, B and C, and minerals such as iron, calcium, phosphorus, potassium, and zinc (Moyo et al., 2011). Due to all of these characteristics, moringa has become a potential candidate as an alternative food in poultry feed mainly for egg production, in addition to acting on the productive aspects, moringa leaves can act by significantly reducing serum cholesterol, egg yolk cholesterol and pigmentation action, and can increase egg shelf life.

Research has revealed that moringa can be considered an important plant with multifunctional applications in livestock nutrition and products, dietary levels of 5\% and $10 \%$ of moringa leaf produced positive results in increasing health, performance, and product quality (El-Hack et al., 2018; Falowo et al., 2018; Mahfuz and Piao, 2019). Despite the good nutritional characteristics that differentiate them from other forages, the ability of the birds to take advantage of their nutrients should be considered, as these animals have a limited ability to take advantage of fibrous feed (Donkor et al., 2013). Also, anti-nutritional factors could limit moringa inclusion levels (El-Hack et al., 2018) which indicates further research on the utilization of enzyme additives may be considered to improve nutrient digestibility (Falowo et al., 2018). On the other hand, dietary levels of $15 \%$ and $20 \%$ of inclusion produced adverse effects on bird's health and performance.

The world's poultry chain is growing fast but laying hens may present reduced performance and egg quality, the increase in nutrient metabolism during egg formation or weakened immune systems, directs dietary nutrients to healthmaintenance (Moula et al., 2019). Laying birds require high amounts of lipids during egg formation suggesting evaluation of alternative potential feed ingredients containing functional nutrients (Pál et al., 2002). Quails are rustic animals compared to broilers and laying hens, in addition, despite undergoing genetic selection programs, they still fall short of laying hens. By passing through genetic selection, birds are known to have lost part of their diverse cecal microbiota, resulting in a probable low digestion of dietary fibers in this organ (Clench and Mathias, 1995). In this sense, due to less advanced genetic selection and rusticity, it is likely that quails still have a high digestibility of foods with a high fiber content, such as moringa, allowing an adequate use of nutrients. Based on the nutritional characteristics of moringa and the physiology of digestion of Japanese quails, the objective is to evaluate the effects of inclusion of moringa in quail diets on performance, egg quality, blood parameters, serum biochemical profile, and behavior of these animals.

\section{MATERIALS AND METHODS}

The trial was carried out in the quail shed located in the experimental warehouse of the Faculty of Agricultural Sciences of the Federal University of Grande Dourados (UFGD), in Dourados, MS, Brazil, in partnership with the University Center of Grande Dourados (UNIGRAN). The experimental protocol was performed with the approval of the Ethics Committee on Animal Use of the University Center of Grande Dourados (Unigran/Dourados) under protocol no. 052/18. The experimental period lasted $66 \mathrm{~d}$, in which the first $10 \mathrm{~d}$ were used to adapt the birds to experimental diets and the remaining days were divided into two cycles of $28 \mathrm{~d}$ each. One hundred and forty-four Japanese quails with approximately 35-d-old (Coturnix coturnix japonica), weighing $148 \pm 14 \mathrm{~g}$, bought from a commercial company, were used in the trial.

The birds were housed in a conventional shed in parallel lots containing five floors. There were two cages per floor $(25 \mathrm{~cm}$ width, $35 \mathrm{~cm}$ length, and $20 \mathrm{~cm}$ height), corresponding to an area of $175 \mathrm{~cm}^{2} /$ housed bird. The lightening program used was $16 \mathrm{~h}$ of light per day. The cages were equipped with a nipple water trough and a chute 
trough, and excreta trimmers were positioned below the cages. Water and feed were provided $a d$ libitum to the quails. The experimental design was completely randomized with four treatments and six replications. The treatments were inclusion of
$0,2,4$ and $6 \%$ of dried and ground moringa leaves in the diet, percentages calculated according to the recommendation of Rostagno et al. (2017) (Table $1)$.

Table 1. Approximate centesimal and calculated composition of the experimental Japanese quail diets with the inclusion of dried and ground moringa leaves (Moringa oleifera)

\begin{tabular}{|c|c|c|c|c|}
\hline \multirow{2}{*}{ Ingredients } & \multicolumn{4}{|c|}{ Level of Moringa oleifera (\%) } \\
\hline & 0.0 & 2.0 & 4.0 & 6.0 \\
\hline Corn, ground grain $8.51 \%$ & 48.69 & 49.00 & 50.00 & 47.10 \\
\hline Soybean bran $46 \%$ & 34.07 & 33.76 & 33.32 & 35.65 \\
\hline Soy oil & 2.000 & 2.000 & 1.340 & $2, .00$ \\
\hline Salt & 0.000 & 0.000 & 0.100 & 0.010 \\
\hline Calcium carbonate & 5.24 & 5.24 & 5.24 & 5.24 \\
\hline Vitamin-Mineral complex ${ }^{1}$ & 4.00 & 4.00 & 4.00 & 4.00 \\
\hline Inert & 6.00 & 4.00 & 2.00 & 0.00 \\
\hline Moringa oleifera & 0.00 & 2.00 & 4.00 & 6.00 \\
\hline Total $(\mathrm{kg})$ & 100.00 & 100.00 & 100.00 & 100.00 \\
\hline \multicolumn{5}{|c|}{ Calculated composition } \\
\hline Metabolizable energy (kcal/kg) & 2,800 & 2,776 & 2,800 & 2,800 \\
\hline Crude protein $(\%)$ & 20.00 & 18.91 & 20.00 & 20.80 \\
\hline Crude fiber $(\%)$ & 2.981 & 3.000 & 3.021 & 3.133 \\
\hline Total lysine $(\%)$ & 1.076 & 1.074 & 1.071 & 1.135 \\
\hline Methionine + Total Cystine (\%) & 0.616 & 0.613 & 0.611 & 0.630 \\
\hline Total Methionine (\%) & 0.336 & 0.335 & 0.336 & 0.347 \\
\hline Total Threonine (\%) & 0.772 & 0.772 & 0.773 & 0.811 \\
\hline Total Tryptophan (\%) & 0.252 & 0.252 & 0.252 & 0.267 \\
\hline Calcium $(\%)$ & 3.020 & 3.033 & 3.047 & 3.068 \\
\hline Total Phosphorus (\%) & 1.919 & 1.919 & 1.920 & 1.928 \\
\hline Sodium $(\%)$ & 0.170 & 0.169 & 0.210 & 0.176 \\
\hline
\end{tabular}

${ }^{1}$ Inclusion of the complex per kg of feed: Calcium (mix) 1,600g/kg, Calcium (max) 400g/kg, Phosphorus (min) $148 \mathrm{~g} / \mathrm{kg}$, Sodium (min) 80g/kg, Methionine (min) 86g/kg, Lysine (min) 72g/kg, Vitamin A (min) 500,000 IU/kg, Vitamin D3 (min) 100,000 IU/kg, Vitamin E (min) 1,248 IU/kg, Vitamin K3 (min) 80mg/kg, Vitamin B1 (min) $80 \mathrm{mg} / \mathrm{kg}$, Vitamin B2 (min) 250mg/kg, Vitamin B6 (min) 150mg/kg, Vitamin B 12 (min) $800 \mathrm{mcg} / \mathrm{kg}$, Folic Acid (min) $25 \mathrm{mg} / \mathrm{kg}$, Pantothenic Acid (min) $500 \mathrm{mg} / \mathrm{kg}$, Biotin (min) $5 \mathrm{mg} / \mathrm{kg}$, Coline (min) 6,800mg/kg, Niacin (min) $1,248 \mathrm{mg} / \mathrm{kg}$, Copper (min) $500 \mathrm{mg} / \mathrm{kg}$, Iron (min) $2,720 \mathrm{mg} / \mathrm{kg}$, Iodine (min) $35 \mathrm{mg} / \mathrm{kg}$, Manganese (min) $3,748 \mathrm{mg} / \mathrm{kg}$, Selenium (min) $15 \mathrm{mg} / \mathrm{kg}$, Zinc (min) $2,000 \mathrm{mg} / \mathrm{kg}$, and Fluoride $(\max ) 1,480 \mathrm{mg} / \mathrm{kg}$.

The moringa was collected at the UFGD experimental farm and only the leaves were used. They were dried at $65^{\circ} \mathrm{C}$ in an oven with forced ventilation. After drying, leaves were ground and could be mixed with the other ingredients of the diets. Moringa leaves bromatological composition is indicated in Table 2, the inclusion in diets considered its composition in the formulation of the diets. The quails were weighed at the beginning and at the end of the experimental period to determine bird weight $(\mathrm{g})$ and weight gain $(\mathrm{g})$. Feed intake (g/bird/day) was evaluated by weighing the feed offered and the leftovers at the end of each stipulated period. Egg mass ( $g$ egg/bird/day), feed conversion by mass (FCm) and feed conversion by dozen (FCdz) were also evaluated. The values were obtained by dividing the averages of performance variables as described below:

$$
\mathrm{FCdz}=\frac{\mathrm{FI}}{\mathrm{DZ}} \mathrm{FCm}=\frac{\mathrm{FI}}{\mathrm{EGGM}}
$$

EGGM = egg mass; DZ = dozens of eggs produced; FI: feed intake. 
Table 2. Chemical composition of dried and ground moringa leaves Moringa oleifera used in experimental Japanese quail diets

\begin{tabular}{|c|c|}
\hline Nutritive value & Dry leaf \\
\hline Dry matter $(\%)$ & 93 \\
\hline Crude Protein $(\%)$ & 26.06 \\
\hline Gross Energy (kcal / kg) & 3000 \\
\hline Ashes $(\%)$ & 12 \\
\hline Ethereal extract (\%) & 8 \\
\hline Crude Fiber $(\%)$ & 15 \\
\hline Calcium (\%) & 2.1 \\
\hline Copper (\%) & 0.0001 \\
\hline Iron $(\%)$ & 0.027 \\
\hline Potassium (\%) & 1.3 \\
\hline Magnesium (\%) & 0.405 \\
\hline Phosphor (\%) & 0.31 \\
\hline Manganese (\%) & 0.008 \\
\hline Selenium $(\%)$ & 0.0026 \\
\hline Zinc $(\%)$ & 0.002 \\
\hline Molybdenum (\%) & 0.0005 \\
\hline Sodium $(\%)$ & 0.1 \\
\hline Sulfur $(\%)$ & 0.74 \\
\hline Arginine $(\%)$ & 1.6 \\
\hline Histidine (\%) & 0.53 \\
\hline Isoleucine (\%) & 1.14 \\
\hline Leucine $(\%)$ & 2.05 \\
\hline Lysine $(\%)$ & 1.2 \\
\hline Methionine (\%) & 0.37 \\
\hline Phenylalanine (\%) & 1.4 \\
\hline Threonine (\%) & 1.08 \\
\hline Tryptophan & 0.58 \\
\hline Valine $(\%)$ & 1.4 \\
\hline B.C. Aspart (\%) & 1.67 \\
\hline B.C.glut (\%) & 2.47 \\
\hline Serine $(\%)$ & 0.84 \\
\hline Glycine (\%) & 0.96 \\
\hline Alanine $(\%)$ & 1.26 \\
\hline Proline (\%) & 1.23 \\
\hline Tyrosine $(\%)$ & 0.91 \\
\hline Cysteine $(\%)$ & 0.36 \\
\hline
\end{tabular}

The average egg production per bird/day (\%) was calculated by counting the eggs laid daily. The viability of the flocks was calculated using the number of deaths subtracted from the number of live birds. The values were converted into percentage at the end of the experimental period. The eggs of the last three days of each experimental period were collected and analyzed for egg quality in the Agricultural Product Analysis Laboratory (FCA/UFGD). The evaluations consist of average egg weight, obtained through the average egg weight at the end of trial periods; specific gravity, obtained by immersing all eggs of each repetition in buckets with different saline solutions $(\mathrm{NaCl})$, whose densities ranged from 1.050 to 1.100 (at intervals of 0.005 , the density was measured using an INCOTERM-OM-5565 densimeter); yolk color on a light surface: the coloration was obtained by two methods: the first by the comparison with the Yolk Color Fan (DSM) using the color closest to the color palette, which varies from 1 to 15 . The second method was the use of a Minolta colorimeter, which evaluates the parameters $\mathrm{L}^{*}$ (luminosity), a* (red) and $b^{*}$ (yellow). Three different and equidistant surface readings were taken. The Chroma was obtained by the relation between the values of $a^{*}$ and $b^{*}$, where the real color of the object is obtained, according to Harder et al. (2010). The Haugh unit correlates egg weight with albumen height and egg quality. The higher the Uh value, the better the egg quality, as expressed by the following formula:

$$
\begin{aligned}
\mathrm{Uh}=100 \log \{\mathrm{H} & -\frac{\left.\sqrt{G\left(30 W^{0.37}\right.}-100\right)}{100} \\
& +1.9\}
\end{aligned}
$$

$\mathrm{H}=$ height of dense albumen (millimeters); $\mathrm{g}$ =gravitational constant $=32 ; \mathrm{W}=$ egg weight ingrams (g).

The egg yolks were weighed, and the albumen weights were estimated by egg weight difference minus egg yolk weight plus shell weight, which was obtained after washing the shell and air drying it for $72 \mathrm{~h}$. The albumen, yolk and shell percentage were obtained by dividing the weights of the respective components by the average egg weight, and the result was multiplied by 100 . The shell weight and thickness were recorded after drying in a forced circulation oven for $24 \mathrm{~h}$. The albumen height and bud height were measured using the Starret $150 \mathrm{~mm}$ digital caliper by measuring the albumen and the yolk. The aggressive behavior (riding and pecking) and the non-aggressive behavior were analyzed (eating, drinking, scratching, and idleness). The procedure was performed by instant focal sampling by direct and continuous observation of a single bird from each cage randomly for five minutes in each cage. This procedure was performed during the final week of experimental period throughout the entire 
light period (7:00 to 18:00 h). The observations of aggressiveness were made according to the methodology described by Savory et al. (1999).

The intensity of body injuries was evaluated according to the presence or absence of lesions in the following regions: back, tail, wings, and head in a single bird of each replication. To assess tonic immobility, the bird was quickly turned over and placed in a supine position on a flat surface. Then, pressure was exerted on its chest for three seconds. To be considered in a state of tonic immobility, the bird should remain immobile for at least ten seconds, according to Heiblum et al. (1998).

At the end of the experimental period, one quail of each replication was randomly chosen for biochemical and blood analysis. Blood samples were collected from the jugular vein of each slaughtered bird and immediately centrifuged for serum separation, after which they were frozen at $-20^{\circ} \mathrm{C}$ until analysis. Biochemical and blood count analyses were performed. Biochemical tests were processed by spectrometry (BioPlus 200), as indicated by the manufacturer of the commercial kits $\quad\left(\right.$ GoldAnalisa $\left.{ }^{\circledR}\right)$. For biochemical analyses (cholesterol, triglycerides, creatinine, phosphatase, lactate, and glucose), $3 \mathrm{~mL}$ of blood samples were collected from the jugular vein without anticoagulants. Blood samples were kept in Eppendorf tubes for one hour at room temperature and centrifuged at $3,500 \mathrm{rpm}$ and $4^{\circ} \mathrm{C}$ for 15 minutes for serum separation. The serum was frozen in a freezer at $-70^{\circ} \mathrm{C}$ until analysis. The samples were prepared and analyzed according to the manufacturer's specifications. Three readings in birds/treatment were taken in a spectrophotometer (Beckman Coulter, DU-800) using a 500-nm wavelength. For blood count analysis (VG and PPT), $2 \mathrm{ml}$ of jugular vein blood were collected in a heparinized syringe immediately after collection using a portable clinical analyzer $\quad\left(\mathrm{i}-\mathrm{STAT}{ }^{\circledR} \mathrm{Co}\right.$. - Abbott Laboratories - USA, Cg8+ ${ }^{\circledR}$ cartridge).

The means of performance data, egg quality and biochemical profile obtained in the two evaluation periods were calculated. The data were tested for statistical assumptions of residue normality and variance homogeneity using the Shapiro-Wilk and Levene tests, respectively. Means that met these assumptions underwent analysis of variance at 5\% probability using the SAS statistical package (version 9.3) (Statistical..., 2012). Subsequently, the effects of moringa inclusion were estimated by analyzing the variables via orthogonal polynomials to obtain regression equations. The means of blood and biochemical parameters were compared between treatments with the Tukey test. Behavior and injury data were evaluated by nonparametric statistical analyses using the Chisquare test and the SAS statistical package (version 9.3) (Statistical..., (2012), considering a significance level of $5 \%$. The level of significance for all variables analyzed was $5 \%$.

\section{RESULTS AND DISCUSSION}

The inclusion of Moringa oleifera in the diets of Japanese quails does not influence the performance variables, except for feed intake, there was a quadratic reduction up to the level of $1.20 \%$ of moringa in the diet (Table 3 ). The main factor that may have caused the reduction of feed intake is the feed's crude fiber content, conferred by the increased inclusion of plant extract in the diet. By increasing moringa levels in the diet, the fibrous fraction also increased. This increase in fiber leads to an increase in the digestion passage rate, with a consequent reduction in nutrient absorption. In addition, it may impair nutrient use, as fiber acts as a physical barrier preventing endogenous enzymes from gaining access to the internal contents of plant cells, reducing nutrient digestion and absorption processes (Braz et al., 2011).

Fiber-rich diets have lower gross energy metabolization coefficients, i.e., a lower energy use due to a lower fiber digestibility in the birds' digestive tract (Macambira et al., 2018). It is noteworthy that in the present study, even with a lower intake, there was no impairment in feed conversion of birds, and conversion values were similar for all treatments. Elkloub et al. (2015) analyzed different levels of moringa inclusion $(0$, 2.0, 4.0 and 6.0\%) in Japanese quail feed and found that the birds with the plant inclusion in diets had a better performance compared to the control group. Quails that received 2\% moringa had a greater weight gain, a lower feed intake, and better feed conversion. Olugbemi et al. (2010) also observed the absence of negative effects on the performance of commercial laying hens fed on 0,5 and $10 \%$ of moringa leaf meal as a substitute for soybean meal. 
Table 3. Performance of Japanese quails fed with different levels of inclusion of dried and ground moringa leaves (Moringa oleifera) in diets

\begin{tabular}{|c|c|c|c|c|c|c|c|}
\hline \multirow{2}{*}{ Variable } & \multicolumn{4}{|c|}{ Level of Moringa oleifera } & \multirow{2}{*}{ MSE } & \multicolumn{2}{|c|}{ Regression } \\
\hline & 0 & 2 & 4 & 6 & & Linear & Quad. \\
\hline AWG $(\mathrm{g})$ & -0.134 & -0.112 & -0.164 & -0.134 & 0.0710 & 0.8437 & 0.9459 \\
\hline Intake (g/bird/day) & 51.56 & 50.01 & 51.23 & 46.73 & 0.5347 & 0.0004 & 0.0417 \\
\hline Laying rate $(\%)$ & 73.67 & 73.67 & 72.04 & 72.99 & 0.5654 & 0.4303 & 0.6446 \\
\hline $\mathrm{FC} / \mathrm{dz}(\mathrm{g} / \mathrm{dz})$ & 29.97 & 28.25 & 30.74 & 27.82 & 0.3722 & 0.3041 & 0.3602 \\
\hline Egg mass (g/bird/day) & 18.02 & 18.24 & 18.95 & 18.20 & 0.2041 & 0.4690 & 0.2244 \\
\hline FC/egg mass $(\mathrm{g} / \mathrm{g})$ & 2.27 & 2.31 & 2.12 & 2.38 & 0.036 & 0.5712 & 0.0620 \\
\hline Variable & & egressi & equatio & & $\mathrm{R}^{2}$ & Effect & Level \\
\hline Intake (g/bird/day) & $\mathrm{Y}=$ & $1393+0$. & $36 X-0.1$ & $6 X^{2}$ & 0.5064 & Quad. & 1.20 \\
\hline
\end{tabular}

AWG: Average weight gain; FC/dz (g/dz): feed conversion per dozen eggs produced; FC/egg mass (g/g): Feed conversion per egg mass produced. Quad: quadratic effect. Regression: linear and quadratic models. $\mathrm{R}^{2}$ : coefficient of determination

In moringa, there are also compounds that can act as antinutritional factors and impair performance, interfering with protein and amino acid digestibility, vitamin and mineral availability, as well as energy metabolism. By examining the nutritional composition and the antinutritional factors of different parts of the Moringa oleifera plant, Macambira et al. (2018) found low levels of tannins, saponins, phytates, oxalates, and protease inhibitors. These compounds reduce protein digestibility as they form saponin-protein complexes and cause damage to the intestinal mucosa by interacting with the lipid bilayer, facilitating the absorption of toxic substances. Protease inhibitors reduce protein digestion of food (Stenico et al., 2017), providing a decreased weight gain and animal growth.

Regarding shell weight, albumen weight, albumen height, shell thickness, bud percentage, albumen percentage, shell percentage, and Haugh unit, no differences were found with the inclusion of moringa (Table 4). The specific gravity, egg weight, yolk weight, yolk height, albumen $\mathrm{pH}$, yolk $\mathrm{pH}$, yolk luminosity $\left(\mathrm{L}^{*}\right)$, yolk red color $\left(\mathrm{a}^{*}\right)$, yolk yellow color $\left(b^{*}\right)$, yolk color shade, and yolk Chroma, were affected by the inclusion of moringa in the diet (Table 5). Regarding specific gravity, there was a decreasing linear effect as the moringa inclusion levels increased. According to Freitas et al. (2011), the high specific gravity results from a better shell quality because there is loss of water in the egg after laying as a result of evaporation, which causes a progressive increase in the air cell and consequently a decrease in egg specific gravity (Quadros et al., 2011).

The egg weight variable showed a negative quadratic effect as the moringa levels increased, reaching a higher weight, the maximum egg wright was obtained with $3.83 \%$ of inclusion. The yolk weight had a linear increasing effect proportional to the increase of moringa inclusion in the diets. For yolk height, there was a positive quadratic effect of moringa inclusion in the diets. These results evidence positive effects of the inclusion of moringa in the diets, even though there is no remuneration related to egg size in marketing eggs. The albumen $\mathrm{pH}$ showed a decreasing linear effect for moringa inclusion levels, unlike yolk pH (negative quadratic effect). The lowest $\mathrm{pH}$ was achieved with a $5.40 \%$ moringa inclusion. According to Siebel (2005), the normal albumen $\mathrm{pH}$ should be around 7.9 and egg yolk should be 6.2 in freshly laid eggs. The average results obtained with the inclusion of moringa in the diets showed a $\mathrm{pH}$ above the desired value. The $\mathrm{pH}$ of eggs increases according to storage days. In the present study, this increase in $\mathrm{pH}$ observed in all tested samples is probably related to the analysis method, since the eggs were analyzed about 48 after oviposition. 
Table 4. Quality determination variables of Japanese quail eggs with inclusion of different levels of dried and ground moringa leaves (Moringa oleifera) in the diets

\begin{tabular}{|c|c|c|c|c|c|c|c|}
\hline \multirow{2}{*}{ Variable } & \multicolumn{4}{|c|}{ Level of Moringa oleifera } & \multirow{2}{*}{ MSE } & \multicolumn{2}{|c|}{$P$-value } \\
\hline & 0 & 2 & 4 & 6 & & Linear & Quad. \\
\hline Specific gravity & $1,082.07$ & $1,082.60$ & $1,080.93$ & $1,076.87$ & 0.6440 & 0.0018 & 0.0558 \\
\hline Egg weight & 11.44 & 11.58 & 12.27 & 11.70 & 0.0772 & 0.0166 & 0.0102 \\
\hline Yolk weight & 3.48 & 3.39 & 3.83 & 3.58 & 0.0477 & 0.0170 & 0.2206 \\
\hline Shell weight & 0.95 & 0.97 & 1.00 & 0.99 & 0.0125 & 0.2125 & 0.5628 \\
\hline Albumen weight & 7.01 & 7.22 & 7.44 & 7.13 & 0.0675 & 0.3170 & 0.0555 \\
\hline Yolk height & 11.89 & 11.65 & 11.60 & 11.87 & 0.0644 & 0.8135 & 0.0353 \\
\hline Albumen height & 5.08 & 5.14 & 5.32 & 5.27 & 0.1005 & 0.3068 & 0.7334 \\
\hline Shell thickness & 0.298 & 0.284 & 0.288 & 0.290 & 0.0029 & 0.4401 & 0.1762 \\
\hline Yolk percentage & 30.43 & 29.36 & 31.19 & 30.68 & 0.2964 & 0.3030 & 0.6166 \\
\hline Album percentage & 61.22 & 62.26 & 60.65 & 60.86 & 0.3509 & 0.3775 & 0.5403 \\
\hline Shell percentage & 8.35 & 8.38 & 8.16 & 8.45 & 0.1112 & 0.9426 & 0.5625 \\
\hline Haugh unit & 92.59 & 92.66 & 93.20 & 93.35 & 0.5004 & 0.4181 & 0.9620 \\
\hline Albumen $\mathrm{pH}$ & 8.80 & 8.58 & 8.51 & 8.18 & 0.0651 & $<0.0001$ & 0.5487 \\
\hline Yolk pH & 6.49 & 6.50 & 6.73 & 6.63 & 0.0465 & 0.0448 & 0.4527 \\
\hline $\mathrm{L}^{*}$ & 56.29 & 54.62 & 53.26 & 51.43 & 0.2831 & $<0.0001$ & 0.8029 \\
\hline Yolk red color $\left(\mathrm{a}^{*}\right)$ & -4.28 & -1.91 & -0.57 & 1.27 & 0.2777 & $<0.0001$ & 0.1311 \\
\hline Yolk yellow color $\left(b^{*}\right)$ & 36.65 & 43.37 & 43.21 & 44.63 & 0.5335 & $<0.0001$ & $<0.0001$ \\
\hline Color tone & -1.45 & -1.42 & -0.61 & 1.54 & 0.1679 & $<0.0001$ & $<0.0001$ \\
\hline Yolk Chroma & 35.92 & 43.43 & 43.23 & 44.65 & 0.5203 & $<0.0001$ & $<0.0001$ \\
\hline
\end{tabular}

Quad.: Quadratic effect

Table 5. Regression equations, coefficient of determination, and maximum and minimum levels obtained for Japanese quail egg quality variables with different levels of inclusion dried and ground moringa leaves of (Moringa oleifera) in the diet of Japanese quails

\begin{tabular}{lcccc}
\multicolumn{1}{c}{ Variable } & Regression equation & $\mathrm{R}^{2}$ & Level \\
\hline Specific gravity & $\mathrm{Y}=1,083.2067-0.8633 \mathrm{X}$ & 0.1523 & - \\
Egg weight & $\mathrm{Y}=11.3463+0.3410 \mathrm{X}-0.0445 \mathrm{X}^{2}$ & 0.1680 & 3.83 \\
Yolk weight & $\mathrm{Y}=3.4581+0.0372 \mathrm{X}$ & 0.6705 & - \\
Yolk height & $\mathrm{Y}=11.8984-0.1920 \mathrm{X}+0.0233 \mathrm{X}^{2}$ & 0.5686 & 4.12 \\
Albumen pH & $\mathrm{Y}=8.8042-0.0957 \mathrm{X}$ & 0.1832 & - \\
Yolk pH & $\mathrm{Y}=6.4665+0.0724 \mathrm{X}-0.0067 \mathrm{X}^{2}$ & 0.3467 & 5.40 \\
Yolk brightness $\left(\mathrm{L}^{*}\right)$ & $\mathrm{Y}=56.2874-0.7961 \mathrm{X}$ & 0.6699 & - \\
Yolk red color $\left(\mathrm{a}^{*}\right)$ & $\mathrm{Y}=-4.0752+0.8997 \mathrm{X}$ & 0.8896 & - \\
Yolk yellow color $\left(\mathrm{b}^{*}\right)$ & $\mathrm{Y}=37.6975+1.3390 \mathrm{X}$ & 0.5339 & - \\
Yolk color tone & $\mathrm{Y}=-1.4202-0.3099 \mathrm{X}+0.1331 \mathrm{X}^{2}$ & 0.8894 & 1.16 \\
Yolk Chroma & $\mathrm{Y}=36.3885+3.5798 \mathrm{X}-0.3800 \mathrm{X}^{2}$ & 0.6734 & 4.71 \\
\hline
\end{tabular}

Regarding yolk luminosity ( $\left.\mathrm{L}^{*}\right)$, there was a linear decreasing effect related to levels of moringa in the diet. Regarding yolk red color ( $\left.\mathrm{a}^{*}\right)$ and yolk yellow color $\left(b^{*}\right)$, there was a linear increasing effect as the inclusion of moringa increased. The yolk is rich in pigments, with carotenoids and riboflavin constituting $0.02 \%$ of the egg dry weight. They are arranged in concentric rings that vary in color depending on the laying bird's diet. The color changes with pigments present in corn or in synthetic substances added to the feed. The yellowish color of the yolk is mainly due to the presence of riboflavin, xanthophylls and $\beta$ - carotene. Alternative plant foods, such as moringa, have different pigment compositions that may change yolk color. In the present study, the addition of moringa to diets favored a more intense yolk color, a factor of great importance to the market, as consumers prefer larger eggs and darker yolks (Seeman, 2000; Preisinger, 2018). Mabusela et al. (2018), using a whole Moringa oleifera seed cake in quail diet and inclusion levels of $0,1,3$ and $5 \%$, also observed an improvement in yolk color according to the increased inclusion of this byproduct, which corroborates with the findings of this study. 
According to the evaluated blood parameters (Table 6), the globular volume $(\mathrm{GV})$ of quails submitted to treatments with inclusion of $0,2,4$ and $6 \%$ of moringa did not differ.

Table 6. Blood and biochemical parameters of Japanese quail with different levels of inclusion of dried and ground moringa leaves (Moringa oleifera) in diets

\begin{tabular}{lcccccc}
\multicolumn{1}{c}{ Variable } & \multicolumn{7}{c}{ Level of Moringa oleifera } \\
\cline { 2 - 7 } & 0 & 2 & 4 & 6 & MSE & P-value \\
\hline GV $(\%)$ & 26.99 & 20.79 & 29.41 & 27.79 & 0.470 & 0.076 \\
TPP (g/dL) & $6.477 \mathrm{~b}$ & $4.272 \mathrm{c}$ & $7.012 \mathrm{a}$ & $6.647 \mathrm{~b}$ & 0.434 & 0.025 \\
Creatinine (mg/dL) & $0.46 \mathrm{a}$ & $0.336 \mathrm{~b}$ & $0.208 \mathrm{~d}$ & $0.269 \mathrm{c}$ & 0.036 & 0.011 \\
Phosphatase (IU) & $428.5 \mathrm{~d}$ & $793.4 \mathrm{~b}$ & $1,340.25 \mathrm{a}$ & $528.7 \mathrm{c}$ & 0.212 & 0.029 \\
Cholesterol (mg/dL) & $90.87 \mathrm{~d}$ & $151.3 \mathrm{~b}$ & $183.28 \mathrm{a}$ & $108.4 \mathrm{c}$ & 0.341 & 0.043 \\
Triglycerides (mg/dL) & $341.7 \mathrm{c}$ & $569.7 \mathrm{~b}$ & $658.97 \mathrm{a}$ & $334.3 \mathrm{~d}$ & 0.473 & 0.003 \\
Lactate (mg/dL) & 3.347 & 4.64 & 4.247 & 3.896 & 0.669 & 0.055 \\
Glucose (mg/dL) & 315.3 & 220.1 & 300.47 & 302.7 & 0.190 & 0.011 \\
\hline
\end{tabular}

${ }^{*}$ Means followed by different lowercase letters in lines differ statistically by Tukey test at 5\% probability. gV: globular volume, TPP: total plasma protein; MSE: mean standard error.

When comparing the values obtained for total plasma protein (TPP), the treatment with $4 \%$ of moringa showed a difference from the treatments with other inclusion levels. Age may influence the diagnostic interpretation of laboratory data in birds (Lumeij, 1997). Montesinos et al. (1997) mentioned that variations in biochemical values, according to age, already occur since the first months of life. Mata (2018) reported that quails submitted to the inclusion of moringa in their diet have a similar hematological profile as that of quails fed on commercial rations, attesting the moringa as an alternative to keep the quails in a healthy and satisfactory clinical state. The concentration of TPP in birds is lower than in mammals, ranging from 2.5 to $6.0 \mathrm{~g} / \mathrm{dL}$ (Thrall, 2004). Therefore, the TPP values found in this study for quails submitted to moringa treatments did not show results outside the normal range for the species. Whereas Lu et al., 2016 founded higher plasma total protein levels with dietary $5 \%$ for moringa leaf meal supplementation, which is a good indicator of the liver's synthetic function, similar to the present findings.

Regarding creatinine, the inclusion of $4 \%$ of EM obtained the lowest value, whereas the control diet resulted in the highest value for this parameter. The values obtained in the present study ranged from 0.2 to $0.4(\mathrm{mg} / \mathrm{dL})$. Schossler et al. (2013) found values ranging from 0.10 to $0.50 \mathrm{mg} / \mathrm{dL}$, demonstrating that EM did not change renal function, keeping levels within normal range. Regarding alkaline phosphatase, the lowest value was found in the $0 \%$ treatment and the highest in the $4 \%$ treatment. Alkaline phosphatase (AP) acts in various tissues, such as bones and intestines. In laying birds, plasma AP activity results mainly from a high osteoblastic activity at the preovulation phase in chickens and at the time of eggshell formation (Campbell, 2015). Alkaline phosphatase increases the concentration of inorganic phosphate acting on eggshell formation (Minafra et al., 2008). A high alkaline phosphatase concentration in birds fed on moringa may indicate a positive influence on eggshell formation metabolism. When relating the egg and shell weight results obtained in the present study, there was an increase in weight for these variables when birds were fed at levels similar as $4 \%$, which may indicate a positive effect of moringa on alkaline phosphatase metabolism.

Regarding cholesterol and triglycerides, the diet with $6 \%$ moringa inclusion was lower when compared to the other treatments. Cholesterol results in quails submitted to diets without the inclusion of moringa $(0 \%)$ were below normal values (100 to $250 \mathrm{mg} / \mathrm{dL}$ ) (Silva et al., 2012; Campbell, 2015). The reduced cholesterol levels of birds fed on high levels of moringa in diets may be related to the characteristic of some phytogenic additives that have lipophilic properties and phenolic compounds that may change the enzymatic activity and bile salts of birds, causing a greater digestibility and transport of lipids and reducing serum cholesterol (Attia et al., 2003, Manafi, 2015). Moringa oleifera exerted no influence on the aggressive and non-aggressive behavior of Japanese quails (Table 7). Adult quails increase interaction (aggressive or non- 
aggressive) as a result of regrouping with the aim of restoring the hierarchy of the group formed (Guzmán et al., 2013). This phenomenon occurs mainly within the first 24 hours after exposure of birds to such social stress (Tenório et al., 2017) or in the first week (Guzmán et al., 2013). Therefore, the greater expression of pecking and riding behaviors may be the result of the adaptation period of these birds until they reestablish the group hierarchy. After this period, there is a decrease in these behaviors, reflecting the absence of differences in the observation periods.

Table 7. Behavior and score of Japanese quail wounds with different levels of inclusion of dried and ground moringa leaves (Moringa oleifera) in diets

\begin{tabular}{|c|c|c|c|c|c|}
\hline \multirow{2}{*}{ Behavior } & \multicolumn{4}{|c|}{ Level of Moringa oleifera (\%) } & \multirow{2}{*}{$P$-value* } \\
\hline & 0 & 2 & 4 & 6 & \\
\hline Aggressive & $30.0 \%(15 / 50)$ & $20.0 \%(10 / 50)$ & $30.0 \%(15 / 50)$ & $20.0 \%(10 / 50)$ & 0.7280 \\
\hline Pecking & $30.0 \%(15 / 50)$ & $20.0 \%(10 / 50)$ & $30.0 \%(15 / 50)$ & $20.0 \%(10 / 50)$ & 0.2215 \\
\hline Mounting & $30.0 \%(15 / 50)$ & $20.0 \%(10 / 50)$ & $30.0 \%(15 / 50)$ & $20.0 \%(10 / 50)$ & 0.4578 \\
\hline Not aggressive & $30.0 \%(15 / 50)$ & $20.0 \%(10 / 50)$ & $30.0 \%(15 / 50)$ & $20.0 \%(10 / 50)$ & 0.5712 \\
\hline Eating & $30.6 \%(15 / 49)$ & $20.4 \%(10 / 49)$ & $28.6 \%(14 / 49)$ & $20.4 \%(10 / 49)$ & 0.2754 \\
\hline Drinking & $30.0 \%(15 / 50)$ & $20.0 \%(10 / 50)$ & $30.0 \%(15 / 50)$ & $20.0 \%(10 / 50)$ & 0.7626 \\
\hline Scratching & $30.0 \%(15 / 50)$ & $20.0 \%(10 / 50)$ & $30.0 \%(15 / 50)$ & $20.0 \%(10 / 50)$ & 0.9908 \\
\hline Idleness & $30.0 \%(15 / 50)$ & $20.0 \%(10 / 50)$ & $30.0 \%(15 / 50)$ & $20.0 \%(10 / 50)$ & 0.1503 \\
\hline TIT & $30.0 \%(15 / 50)$ & $20.0 \%(10 / 50)$ & $30.0 \%(15 / 50)$ & $20.0 \%(10 / 50)$ & 0.6154 \\
\hline \multicolumn{6}{|l|}{ Injury score } \\
\hline 0 & $10 \%(10 / 100)$ & $5 \%(5 / 100)$ & $15 \%(15 / 100)$ & $10 \%(10 / 100)$ & \multirow{4}{*}{0.0031} \\
\hline 1 & $10 \%(10 / 100)$ & $16 \%(16 / 100)$ & $2 \%(2 / 100)$ & $5 \%(5 / 100)$ & \\
\hline 2 & $5 \%(5 / 100)$ & $4 \%(4 / 100)$ & $7 \%(7 / 100)$ & $10 \%(10 / 100)$ & \\
\hline 3 & $0 \%(0 / 100)$ & $0 \%(0 / 100)$ & $1 \%(1 / 100)$ & $0 \%(0 / 100)$ & \\
\hline
\end{tabular}

Tonic immobility time (TIT) also showed no significant effects. Similar results were also found by Marques et al. (2010). This behavior is the last anti-predatory defense response of some species. It is characterized by pretending to be dead to create an opportunity to escape by inducing relaxation of the predator's attention (Brunelli et al., 2018). Regarding injury scores, there was an effect of the inclusion of moringa in the diets, and the inclusion of $2 \%$ in the diets caused a high frequency of minor injuries. The inclusion of moringa was expected to be capable of producing anxiolytic effects in birds, but just as Gravena et al. (2009) pointed out using valerian, the inclusion of moringa in diets was not able to exert sedative or anxiolytic effects.

Marques et al. (2010), using chamomile as a phytotherapic additive for quails at the laying phase, did not observe a sedative or anxiolytic effect, showing no significant reduction of bodily injuries. Thus, the results of the present study were similar to the literature, moringa, as chamomile and valerian, has no calming effects on birds. The lesions resulting from the inclusion of moringa were mild and were only higher at the
$2 \%$ level of inclusion. At the other levels, they were similar as the control diet, which may indicate that no deleterious effects of inclusion of these compounds to diets are noted. Despite positive results founded in the present study on the potential use of Moringa oleifera in quail diets to increase egg quality, without compromising performance, biochemical profile, blood parameters, and bird behavior the possibility of its use in quail diets is evident, however it is known that some challenges are still present, such as the presence of antinutritional factors (Falowo et al., 2018), which still requires studies to further improve moringa dietary benefits.

\section{CONCLUSION}

Up to $3.83 \%$ of Moringa oleifera can be included in Japanese quail diet demonstrating general benefits to quail production, improving egg quality without compromising performance, biochemical profile, blood parameters, and bird behavior. Higher levels of Moringa oleifera inclusion also can bring benefits, however they showed occasional improvements in the evaluated variables. 


\section{REFERENCES}

ATTIA, Y.A.; TAG EL-DIN, A.E.; ZEWEIL, H.S. et al. Nutritional evaluation of nigella seed meal and the effect of microbial phytase and amino acids supplementations on its feeding value for Japanese quail. Egypt. J. Nutr. Feeds, v.6, p.201-217, 2003.

BOKA, J.; MAHDAVI, A.H.; SAMIE, A.H. et al. Effect of different levels of black cumin (Nigella sativa L.) on performance, intestinal Escherichia coli colonization and jejunal morphology in laying hens. J. Anim. Physiol. Anim. Nutr., v.98, p.373-383, 2014.

BRAZ, N.; FREITAS, E.R.; BEZERRA, R.M. et $a l$. Fibra na ração de crescimento e seus efeitos no desempenho de poedeiras nas fases de crescimento e postura. Rev. Bras. Zootec., v.40, p.2744-2753, 2011.

BRUNELLI, P.F.; ROMANIA, H.F.; CULTRI, G.R.S. et al. Bem-estar e qualidade de ovos de codornas alimentadas com extratos de camomila e passiflora. Bol. Inst. Anim., v.75, p.1-11, 2018.

CAMPBELL, T.W. Hematologia e bioquímica clínica veterinária. São Paulo: Roca, 2015. 678p.

CLENCH, M.H.; MATHIAS, J.R. The avian cecum: a review. Wilson Bull., v.107, p.93-121, 1995.

DONKOR, A.M.; GLOVER, R.L.K.; ADDAE, D. et al. Estimating the nutritional value of the leaves of moringa oleifera on poultry. Food. Nutr. Sci., v.4, p.1077-1083, 2013.

EL-HACK, A.; MOHAMED, E.; ALAGAWANY, M. et al. Effect of forage moringa oleifera L.(moringa) on animal health and nutrition and its beneficial applications in soil, plants and water purification. Agriculture, v.8, p.145, 2018.

ELKLOUB, K.; MOUSTAFA, M.E.; GHAZALAH, A.A. et al. Effect of dietary nanosilver on broiler performance. Int. J. Poult. Sci., v. 14, p. 177-182, 2015.

FALOWO, A.B.; MUKUMBO, F.E.; IDAMOKORO, E.M. et al. Multi-functional application of Moringa oleifera Lam. in nutrition and animal food products: a review. Food Res. Int., v.106, p.317-334, 2018.
FREITAS, L.W.; PAZ, I.C.D.L.A.; GARCIA, R.G. et al. Aspectos qualitativos de ovos comerciais submetidos a diferentes condições de armazenamento. Agrarian, v.4, p.66-72, 2011.

GALLÃO, M.I.; DAMASCENO, L.F.; BRITO, E.S. Avaliação química e estrutural da semente de moringa. Rev. Ciênc. Agron., v.37, p.6-109, 2006.

GRAVENA, R.A.; MARQUES, R.H.; SILVA, J.D.T. et al. Uso da Valeriana officinalis em dietas de codornas japonesas na fase de postura. Biotemas, v.22, p.185-191, 2009.

GUZMÁN, D.A.; PELLEGRINI, S.; KEMBRO, J.M. et al. Social interaction of juvenile Japanese quail classified by their permanence in proximity to a high or low density of conspecifics. Poult. Sci., v.92, p.2567-2575, 2013.

HARDER, M.N.C.; SPADA, F.P.; SAVINO, V.J.M. et al. Coloração de cortes cozidos de frangos alimentados com urucum. Food Sci. Technol., v.30, p.507-509, 2010.

HEIBLUM, R.; AIZENSTEIN, O.; GVARYAHU, G. et al. Tonic immobility and open field responses in domestic fowl chicks during the first week of life. Appl. Anim. Behav. Sci., v.60, p.347-357, 1998.

LU, W.; WANG, J.; ZHANG, H.J.; WU, S.G.; QI, G.H. Evaluation of Moringa oleifera leaf in laying hens: Effects on laying performance, egg quality, plasma biochemistry and organ histopathological indices. Ital. J. Anim. Sci., v.15, p.658-665, 2016.

LUMEIJ, J.T. Avian clinical biochemistry. In: KANEKO, J.J. Clinical biochemistry of domestic animals. San Diego: Academic, 1997. p.857-883.

MABUSELA, S.P.; NKUKWANA, T.T.; MOKOMA, M. et al. Layer performance, fatty acid profile and the quality of eggs from hens supplemented with Moringa oleifera whole seed meal. S. Afr. J. Anim. Sci., v.48, p.234-243, 2018.

MACAMBIRA, G.M.; RABELLO, C.B.V.; NAVARRO, M.I.V. et al. Caracterização nutricional das folhas de Moringa oleifera (MOL) para frangos de corte. Arq. Bras. Med. Vet. Zootec., v.70, p.570-578, 2018.

MAHFUZ, S.; PIAO, X.S. Application of Moringa (Moringa oleifera) as natural feed supplement in poultry diets. Animals, v.9, p.431, 2019. 
MANAFI, M. Comparison study of a natural nonantibioticgrowth promoter and a commercial probiotic ongrowth performance, immune response and biochemical parameters of broiler chicks. J. Poult. Sci., v.52 p.274-281, 2015.

MARQUES, R.H.; GRAVENA, R.A.; SILVA, J.D.T. et al. Inclusão da camomila no desempenho, comportamento e estresse em codornas durante a fase de recria. Cienc. Rural, v.2, v.40, p.415-420, 2010.

MATA, Y.D.D. Análise hematológica de codornas europeias alimentadas com diferentes níveis de moringa (moringa oleifera). 2018, 40f. Dissertação (Mestrado) - Universidade Federal Rural do Semi-Árido, Mossóro, RN.

MINAFRA, C.S.; MORAES, G.H.K.; RODRIGUES, A.C.P. et al. Perfil bioquímico e nutricional do ácidoglutâmico e da vitamina $\mathrm{K}$ no soro e no fígado de frangos de corte de 1 a 21 dias de idade. Rev. Bras. Zootec., v.37, p.1973-1977, 2008.

MONTESINOS, A.; SAINZ, A.; PABLOS, M.V. et al. Hematological and plasma biochemical reference intervals in young white storks. J. Wildl. Dis., v.33, p.405-412, 1997.

MOULA, N.; SADOUDI, A.; TOUAZI, L. et al. Effects of stinging nettle (Urtica dioica) powder on laying performance, egg quality, and serum biochemical parameters of Japanese quails. Anim. Nut., v.5, p. 410-415, 2019.

MOYO, B.; MASIKA, P.J.; HUGO, A. et al. Nutritional characterization of moringa (Moringa oleifera Lam.) leaves. Afr. J. Biotechnol., v.10, p.12925-12933, 2011.

NDUBUAKU, U.M.; UCHENNA, N.V.; BAIYER, K.P. et al. Anti-nutrient, vitamin and other phytochemical compositions of old and succulent moringa (Moringa oleifera Lam) leaves as influenced by poultry manure application. Afr. J. Biotechnol., v. 14, p. 2502-2509, 2015.

OLUGBEMI, T.S.; MUTAYOBA, S.K.; LEKULE, F.P. Effect of Moringa (Moringa oleifera) inclusion in cassava based diets fed to broiler chickens. Int. J. Poult. Sci., v.9, p.363-367, 2010.
PAL, L.; GROSSMANN, R.; DUBLECZ, K. et al. Effects of glucagon and insulin on plasmaglucose, triglyceride, and triglyceride-rich lipoprotein concentrations in laying hens fed diets containing different types of fats. Poult. Sci., v.81, p.1694-1702, 2002.

PREISINGER, R. Innovative layergenetics to handleglobal challenges in egg production. $\mathrm{Br}$. Poult. Sci., v.59, p.1-6, 2018.

QUADROS, D.G.; JESUS, T.R.; KANEMATSU, C.H. et al. Qualidade de ovos degalinha comercializados em Barreiras, BA, estocados em diferentes condições de temperatura. Rev. Acad. Cienc. Anim., v.9, p.363-369, 2011.

ROSTAGNO, H.S.; ALBINO, L.F.T.; HANNAS, M.I. et al. Tabelas brasileiras para aves e suínos: composição de alimentos e exigências nutricionais. 4ed. Viçosa, MG: UFV Departamento de Zootecnia, MG, 2017. 488p.

SAVORY, C.J.; MANN, J.S.; MACLEOD, M.G. Incidence of pecking damage in growing bantams in relation to food form, group size, stocking density, dietary tryptophan concentration and dietary protein source. Br. Poult. Sci., v.40, p.579584, 1999.

SCHOSSLER, J.E.W.; SERAFINI, G.M.C.; LUCAS, S.S. Valores laboratoriais e aspectos histológicos de codornas domésticas (Coturnix coturnix japonica). Rev. Cien. Elet. Med. Vet., v.21, p.1-13, 2013.

SEEMANN, M. Factors which influence pigmentation. Lohmann Inf., v.24, p.20-24, 2000.

SEIBEL, N.F. Transformações bioquímicas durante o processamento do ovo. In: SOUZSOARES, L.A.; SIEWERDT, F. Aves e ovos. Pelotas: UFPEL. 2005, p.77-90.

SILVA, J.E.S.; MOURA, A.M.A.; NOGUEIRA, R.A. Efeito dos ácidosgraxos essenciais sobre lipidemia e vascularização da membrana vitelina de codornas japonesas. Arq. Bras. Med. Vet. Zoot., v. 64, p. 1603-1612, 2012.

STATISTICAL analysis system. SAS PC Windows Version 9.2.0. Cary: SAS Institute Inc., 2012. 


\section{Garcia et al.}

STENICO, M.E.; LORENZI, A.S.; SILVA, C.S. et al. Inibidores de proteases produzidos por cianobactérias: uma revisão. Oecol. Aust., v.16, p.183-209, 2017.

TENÓRIO, K.I.; SGAVIOLI, S.; RORIZ, B.C. et al. Effect of chamomile extract on the welfare of laying Japanese quail. Rev. Bras. Zootec., v.46, p.760-765, 2017.
THRALL, M.A. Laboratory evaluation of plasma and serum proteins. In: THRALL, M.A.; WEISER, G.A.; ROBIN, W. Veterinary hematology and clinical chemistry. Philadelphia: Lippincott Williamsp, 2004. p.401-412. 